\title{
Identifying Variables Influencing Tenant Affordability to Pay Rent in Ipoh City Council Public Housing
}

\author{
Nor Aini Salleh ${ }^{1}$, Nor'Aini Yusof ${ }^{2}$, Noraini Johari ${ }^{3}$, Yuhainis Talib ${ }^{4}$ \\ 1,3,4 Universiti Teknologi MARA (Perak), 32610 Bandar Baru Seri Iskandar, Perak, Malaysia \\ ${ }^{2}$ School of Housing, Building and Planning, Universiti Sains Malaysia, 11800 Pulau Pinang Malaysia
}

\begin{abstract}
Affordability reflects the challenges faced by households in balancing the real cost of housing and non housing expenditures against income limitations placed upon the household. Various methods have been introduced to measure housing affordability among households. This study was undertaken to identify the variables influencing tenant affordability to pay rent. Data was obtained through questionnaire distribution on 350 MBI public housing tenants using the strata sampling technique. This study found that only ethnic group variable significantly influenced the ability to pay rent. The study's findings proved that different ethnic groups faced different housing costs liabilities attributable to different socioeconomic status.
\end{abstract}

\section{Introduction}

Housing is a medium in macroeconomic development and a tool for poverty eradication. Ironically, access to housing ownership has eluded the lower income groups, most evidently among those living below the poverty line. Affordability issues are controversial but they affect decisionmaking regarding home ownership [4]. Policies, guidelines and legislation play critical roles in ensuring housing are affordable to the lower income groups [12]. Home ownership is one of the objectives of the housing policy formulated by the government. Not everyone can afford owning a house hence renting is the closest alternative available to those less fortunate in their quest for a dwelling. Housing affordability is is the main obstacle to housing for the poor [37]. While rent arrears and tenant affordability have attracted relatively substantial research interest in developed countries; the relationship between the two has been rather neglected in the context of developing countries. Most contributions regarding tenant affordability in developing countries focused on types of housing being rented by the low income group for example studies done by [26]. The aim of the present paper is to identify the variables influencing tenant affordability to pay rent amongst tenants of public housing in Ipoh City Council, Malaysia.

\section{Framework on Affordability Theory towards Housing}

Affordability reflects the challenges faced by households in balancing the real cost of housing and non housing expenditures against income limitations placed upon the household [33]. Tenant's affordability is defined as $30 \%$ of income received used towards rental payment $[6,8,19]$ also viewed housing affordability as a rental liability to the tenant or a cost liability that must be borne by the 
owner [8] and [19] concurred with [35] views that tenants' housing problems are apparent through high rental obligations. Lower income households and high housing costs entitle them to housing benefits. Households have to occupy small sized and low quality dwellings as trade-offs for their lack of affordability in obtaining suitable housing [21,28]. Various methods have been introduced by past researchers to measure housing affordability levels among households which are generally used to analyse the financial ability displayed by households [23]. The use of affordability measurements presents various benefits not only to policy makers but also greatly aids households in determining their housing entitlements [18]. Monthly housing costs borne by house owners differ from monthly housing costs borne by tenants. Housing costs for owners comprise four important components namely housing instalment cost, energy and utility costs, property taxes and other operational costs. On the other hand, housing costs for tenants consist of only two important components which are tenancy contract and energy and utility costs [7].

The variables frequently used by past researchers to measure affordability among tenants include i) Household Type: Households with more children bear higher housing costs compared to households with fewer children [7,27] as are households with children compared to childless households [6]. Singles household familial structures reflect different affordability levels than households with families. Adult children staying with their families are believed to help the family earn more income [22]. Hence [15] in his study has classified working children under a separate unit from parents in his analysis while dependent children were considered as one unit with the parents [15] reiterated that values for housing and non-housing vary depending on size and age of household group consumption. Larger households require bigger houses and the attendant higher income needed to achieve the same level of wellbeing enjoyed by smaller households [7] found that households headed by women, senior citizens and single mothers bear higher housing cost liabilities [7] also proved that race and ethnicity of households indicated differing housing cost liabilities whereby black and Hispanic households faced housing problems and problematic neighbours. These formed two out of five indicators used to study households' lack of affordability in the United States.

The next variable used is ii) Household Income: A household is perceived to have affordability issues when its income is inadequate for household expenditures and other needs besides housing. Debates on affordability measurement usually centre on accurate measurement of resources obtained by households i.e. whether income should be calculated on gross or after tax deduction to yield net income; and methods of calculation of sources of income [15] theorized that income measurement should be based on household net expendable income after all taxes have been deducted and housing benefits have been factored in as income. Housing benefits are subsidies given to deserving low income households to aid in housing costs and not to be used for other needs. According to prevailing economic theories, the concept of income must be calculated to include nonfinancial and future incomes [15]. A study conducted by [18] found that 5 economic circles whereby households obtain their resources (in cash or non-cash) to fulfill their needs are through (a) local economy, internal households (b) informal economy, familial expansion and close relationships (c) social economy, neighbors and group-based communities and agencies (d) formal economy, based on formal markets and (e) state economy, governments.

Researchers also used iii) Household Expenditure variable which may be categorized into two basic categories namely housing expenditure and non-housing expenditure. Health services were not included as they were provided by the government [33] indicated that a standard low budget non housing expenditure for two adults and two children in the United States includes food, household fittings and operations, transportation, clothing, medication, childcare and other goods and services. The next variable is iv) Type of Work: The type of work done by a household has a close relationship with the level of education of the household; low education level results in lowly paid jobs being secured [25]. Households who work as lower skilled laborers can only support a small sized household if there are two members of the family working otherwise they will have to settle for a lower quality housing or both [14].

Researchers include v) Level of Education as a variable to study tenant affordability where a higher level of education guarantees a good job and the salary obtained is able to guarantee a better 
quality of life [20,21,31] found that lower educated households face problems of affordability [28] proved that households with lower level of education face difficulties procuring standard quality housing as they have to spend the bulk of their income on housing. Findings from a study by [14] showed that it was difficult for a lower educated and lower income American to own his dream house due to increase in house prices and decrease in wages received. The last variable used is vi) Housing Location where households living in urban areas bear higher housing liabilities [4,21]. A good location comprises community facilities in the vicinity, proximity to markets, shorter distance between the workplace and the housing and ease to find public transportation [27]. Location characteristics were combined to evaluate effects on housing affordability. From all practical aspects, rental differences between one estate to another is determined by factors such as location, transportation linkages, the estate's facilities and environment [16]. High housing costs are trade-offs made by the lower income groups in choosing houses located far from their workplaces in urban areas [19] concluded in his study that economic sector development, migration patterns, changes in housing policy and other factors have caused discrepancies in housing costs, meriting a study on household geographical distribution. Findings of his study indicated that poverty rates among households differ according to region.

\section{Methodology}

This study's population comprises tenants of all 1,008 tenanted public housing units under Ipoh City Council (MBI) according to a list provided by MBI's public housing management. Selection of this study's sample is through two tier strata sampling stratified into type of housing and type of tenants whether those facing rent arrears or not facing rent arrears. This study employed face-to-face self-administered questionnaires using pencil and paper. The questionnaire was broken down into a few main sections namely Section A: Tenant Background; Section B: Information on Tenant's Affordability; Section C: Satisfaction towards Housing, Environment and Management; and Section D: Rent Arrears amongst Public Housing Tenants. Section A aims at scrutinizing information on the background of heads of households; Section B studies the level of affordability among tenants; Section $\mathrm{C}$ aims to investigate the level of satisfaction towards housing and the services provided by the public housing management; and Section $\mathrm{D}$ was formulated to look into detail matters regarding rent arrears faced by tenants. A total of 350 questionnaires were distributed to the selected sample. This study successfully achieved return questionnaires totaling 301 samples giving a response rate of $86 \%$. The rest of the questionnaires were not returned due to absence of tenants at home, the occupant not being the real tenant, tenants too scared to admit they were facing rent arrears and tenants' refusal to cooperate with the researcher.

\section{Results and Discussion}

\subsection{Analysis of Relationship between Tenant Affordability Factors with Rent Arrears}

The dependent variable for this study is whether or not there is an incidence of rent arrears. Independent variables for this study are types of household, ethnic groups, levels of education, types of work, household incomes, household expenditures and types of public housing. Since the dependent variable for this study is dichotomy data, the logistic regression binary analysis method is the most suitable method to be employed [36].

Table 1: Code for Dependent Variable

\begin{tabular}{|c|c|}
\hline Dependent Variable & Value \\
\hline Never Incurred & 0 \\
\hline Have Incurred & 1 \\
\hline
\end{tabular}


The analysis was done with the aid of SPSS version 12.1 software. The rent arrears dependent variable consists of two categories which are: never incurred (0) and have incurred (1) as shown in Table 1. Table 2 shows there are 295 study samples and 6 missing cases.

Table 2: Study Sample

\begin{tabular}{|c|c|c|c|}
\hline \multicolumn{2}{|c|}{ No Weightage Case } & N & Percentage \\
\hline \multirow{3}{*}{ Selected Case } & Inclusive of Analysis & 295 & 98.0 \\
\cline { 2 - 4 } & Missing Cases & 6 & 2.0 \\
\cline { 2 - 4 } & Total & 301 & 100.0 \\
\hline \multicolumn{2}{|c|}{ Unselected Case } & 0 & .0 \\
\hline \multicolumn{2}{|c|}{ Total } & 301 & 100.0 \\
\hline
\end{tabular}

The logistic regression analysis results are divided into two steps i.e. (a) step 0 (null model) and (b) step 1 (model with predictor). Table 3 shows that $58.6 \%$ of the respondents were classified to have been observed and predicted to have incurred rent arrears while the model with predictor in Table 4 indicates the real classification of respondents achieved was $69.5 \%$ i.e. 74 respondents were observed to have never incurred rent arrears and were predicted to have never incurred rent arrears. 131 respondents were observed to have incurred arrears and predicted to have incurred arrears in rent payment.

The Omnibus test as shown in Table 5 is the null hypothesis testing result where the beta multiplier is zero and this result has caused the hypothesis to be rejected because the $\mathrm{p}$ value equals zero. The Hosmer and Lemeshow test (Table 7) shows an insignificant Chi value-to the power of two $\left(\mathrm{X}^{2}=9.101\right.$, $\mathrm{df}=8, \mathrm{p}=0.334$ ) with a significant level $\mathrm{p}=0.05$.

These findings indicate the compatibility of the model with the data collected in the study [34]. Meanwhile Table 6 shows Cox and Snell's R value to the power of two ie 0.206 , indicating that there was only $20.6 \%$ improvement on the model with predictor as compared with the null model.

Table 3: Classification $(a, b)$

\begin{tabular}{|c|c|c|c|c|c|}
\hline \multicolumn{3}{|c|}{ Observed } & \multicolumn{3}{|c|}{ Prediction } \\
\hline & & & \multicolumn{2}{|c|}{ Facing Arrears } & \multirow[b]{2}{*}{ Real Percentage } \\
\hline & & & Never Faced & Have Faced & \\
\hline \multirow[t]{3}{*}{ Step 0} & Facing Arrears & Never Faced & 0 & 122 & .0 \\
\hline & & Have Faced & 0 & 173 & 100.0 \\
\hline & & ll Percentage & & & 58.6 \\
\hline
\end{tabular}

Table 4: Classification (a)

\begin{tabular}{|c|c|c|c|c|c|}
\hline \multicolumn{3}{|c|}{ Observed } & \multicolumn{3}{|c|}{ Prediction } \\
\hline & & & \multicolumn{3}{|c|}{ Facing Arrears } \\
\hline & & & Never Faced & Have Faced & Real Percentage \\
\hline Step 1 & Facing Arrears & Never Faced & 74 & 48 & 60.7 \\
\hline & & Have Faced & 42 & 131 & 75.7 \\
\hline & & all Percentage & & & 69.5 \\
\hline
\end{tabular}

Table 5: Omnibus Test

\begin{tabular}{lcccc}
\hline & & Chi-power & Df & Sig. \\
\hline Step 1 & Step & 67.983 & 33 & .000 \\
& Block & 67.983 & 33 & .000 \\
& Model & 67.983 & 33 & .000 \\
\hline
\end{tabular}

Table 6: Model Summary Table

\begin{tabular}{cccc}
\hline Step & $\mathbf{- 2}$ Log likelihood & $\begin{array}{c}\text { Cox \& Snell's R to the } \\
\text { Power of Two }\end{array}$ & Nagelkerke's R to the Power of Two \\
\hline $332.112(a)$ & .206 & .277 \\
\hline
\end{tabular}


Table 7: Hosmer and Lemeshow Test

\begin{tabular}{cccc}
\hline Step & Chi-Power & Df & Sig. \\
\hline 1 & 9.101 & 8 & .334 \\
\hline
\end{tabular}

Table 8 shows the final results for independent variables used to predict affordability factors influencing rent arrears amongst tenants at MBI public housing. Analysis results revealed that only one independent variable (in bold) influences rent arrears prevailing amongst tenants and that was ethnic group variable (household type).

Table 8: Variables in Equations

\begin{tabular}{|c|c|c|c|c|c|c|c|}
\hline & VARIABLE & B & S.E. & Wald & Df & Sig. & $\operatorname{Exp}(B)$ \\
\hline ;Step 1 (a) & Type of work & & & 2.874 & 5 & .719 & \\
\hline & Type of work (1) & -.358 & .412 & .755 & 1 & .385 & .699 \\
\hline & Type of work (2) & -.064 & .558 & .013 & 1 & .908 & .938 \\
\hline & Type of work (3) & -.574 & .459 & 1.561 & 1 & .211 & .563 \\
\hline & Type of work (4) & -.698 & .672 & 1.078 & 1 & .299 & .498 \\
\hline & Type of work (5) & -.053 & .432 & .015 & 1 & .903 & .949 \\
\hline & No. Of schooling household & & & 1.584 & 2 & .453 & \\
\hline & No. Of schooling household (1) & -.951 & .756 & 1.584 & 1 & .208 & .386 \\
\hline & Total income & & & 2.753 & 5 & .738 & \\
\hline & Total income (1) & -.737 & 1.450 & .258 & 1 & .611 & .479 \\
\hline & Total income (2) & -1.247 & 1.345 & .860 & 1 & .354 & .287 \\
\hline & Total income (3) & -1.236 & 1.330 & .864 & 1 & .353 & .290 \\
\hline & Total income (4) & -.854 & 1.276 & .447 & 1 & .504 & .426 \\
\hline & Total income (5) & -1.179 & 1.089 & 1.172 & 1 & .279 & .308 \\
\hline & Housing costs(1) & -.485 & .533 & .828 & 1 & .363 & .616 \\
\hline & Non housing costs & & & 7.981 & 5 & .157 & \\
\hline & Non housing costs (1) & .503 & 1.280 & .155 & 1 & .694 & 1.654 \\
\hline & Non housing costs (2) & -.163 & 1.277 & .016 & 1 & .898 & .850 \\
\hline & Non housing costs (3) & -.162 & 1.186 & .019 & 1 & .891 & .851 \\
\hline & Non housing costs (4) & 1.209 & 1.125 & 1.156 & 1 & .282 & 3.352 \\
\hline & Non housing costs (5) & -.305 & 1.080 & .080 & 1 & .777 & .737 \\
\hline & Type of housing & & & 3.463 & 4 & .483 & \\
\hline & Type of housing (1) & .181 & .386 & .220 & 1 & .639 & 1.198 \\
\hline & Type of housing (2) & .470 & .478 & .967 & 1 & .325 & 1.600 \\
\hline & Type of housing (3) & .784 & .850 & .850 & 1 & .356 & 2.190 \\
\hline & Type of housing (4) & 1.025 & .609 & 2.831 & 1 & .092 & 2.788 \\
\hline & Ethnic group & & & 23.312 & 3 & .000 & \\
\hline & Ethnic group (1) & .763 & .603 & 1.602 & 1 & .206 & 2.146 \\
\hline & Ethnic group (2) & -1.227 & .447 & 7.524 & 1 & .006 & .293 \\
\hline & Ethnic group (3) & .461 & .473 & .951 & 1 & .329 & 1.586 \\
\hline & $\begin{array}{l}\text { Non-working non-schooling } \\
\text { household(1) }\end{array}$ & -.765 & .885 & .747 & 1 & .387 & .465 \\
\hline & Total household & & & 2.673 & 2 & .263 & \\
\hline & Total household (1) & -.332 & .362 & .843 & 1 & .358 & .717 \\
\hline & Total household (2) & .798 & .642 & 1.543 & 1 & .214 & 2.221 \\
\hline & Level of education & & & 1.495 & 4 & .828 & \\
\hline & Level of education (1) & .492 & .450 & 1.194 & 1 & .275 & 1.635 \\
\hline & Level of education (2) & .631 & 1.078 & .342 & 1 & .558 & 1.879 \\
\hline & Level of education (3) & .045 & .346 & .017 & 1 & .896 & 1.046 \\
\hline & No. Of working household(4) & -.085 & .633 & .018 & 1 & .893 & .918 \\
\hline & Constant & 3.110 & 1.557 & 3.988 & 1 & .046 & 22.417 \\
\hline
\end{tabular}




\section{Conclusion}

This study contributes to the existing body of knowledge on rent arrears and tenant affordability. Past studies have focused on the rent arrears and management factors [5]; [29], causes of rent default in broader context [26], measuring affordability in public housing rents [4] thus, providing only a limited understanding of the extent of variables that influenced rent arrears amongst the tenants. The present study revealed that ethnic group variables have made a significant effect on rent arrears prevailing in MBI public housing. At the same time, this study supports findings of a study conducted by [10] in the United States. The study done by [10] was a comparative study between owners and tenants. Their study proved that ethnicity also influenced housing affordability. The migrant population comprising Hispanic and black households tend to occupy high density housing as compared to white and non-white Native Americans. This was due to the lower socioeconomic standing among blacks and Hispanics. Besides that, studies carried out by [24], [19], [1], [4] and [21] also found that different ethnic groups and races faced differing housing costs due to their differing socioeconomic status. This study on the other hand, revealed that variables such as household structure, type of work, level of education, type of housing, household income and household expenditure on housing costs and non-housing costs do not have significant influences on rent arrears prevailing amongst tenants in MBI public housing. The implication of this study's findings indicated that there are small numbers of tenants from the Indian ethnic group facing rent arrears due to affordability factors caused by a low socioeconomic standing. The housing management ought to closely look into this problem to identify the root cause of the problem and what form of aid can be offered to these problematic tenants.

\section{References}

1. Boheim, R., \& Taylor, M. P. (2000). My Home was My Castle: Evictions and Repossessions in Britain. Housing Economics, 9: 287 - 319.

2. Bramley, G. (1992). Homeownership Affordability in England. Housing Policy Debate, 3(3), 815-853.

3. Bramley, G., \& Karley, N. K. (2005). How Much Extra Affordable Housing is Needed in England. Housing Studies, 20(5), 685-715.

4. C.M.Hui, E. (2001). Measuring Affordability in Public Housing from Economic Principles: Case Study of Hong Kong. Urban Planning and Development, 127(1), 34-49.

5. Cameron, S., \& Gilroy, R. (1997). Managing Rent Arrears. Local Government Studies, 23(1), 32-47.

6. Chaplin, R., \& Freeman, A. (1999). Towards an Accurate Description of Affordability. Urban Studies, 36(11), 1949-1957.

7. Chi, P. S., \& Laquatra, J. (1998). Profiles of Housing Cost Burden in the United States. Family and Economics Issues, 19(2), 175-193.

8. Fiscelli, C. (2005). New Approaches to Affordable Housing: Overview of the Housing Affordability Problem Los Angeles: Reason Foundation Policy Study.

9. Ford, J., \& Seavers, J. (1998). Housing associations and rent arrears : attitudes, beliefs and behaviour. Coventry: Chartered Institute of Housing.

10. Friedman, S., \& Rosenbaum, E. (2004). Nativity Status and Racial/Ethnic Differences in Access to Quality Housing: Does Homeownership Bring Greater Parity? HOUSING POLICY DEBATE, 15(4), 1-37.

11. Gabriel, M., et al. (2005). Conceptualising and Measuring the Housing Affordability Problem: Australian Housing And Urban Research Institute.

12. Ghani, S., \& Lee, L. M. (1997). Low Cost Housing in Malaysia: Utusan Publications \& Distributors Sdn Bhd.

13. Gilderbloom, J. I. (1985). Social Factors Affecting Landlords in the Determination of Rent Contemporary Ethnography, Urban life, 14(2), 155-179. 
14. Gyourko, J., \& Linneman, P. (1993). The Affordability of the American Dream: An Examination of the Last 30 Years. Housing Research, 4(1), 39-72.

15. Hancock, K. E. (1993). 'Can Pay? Won't Pay?' or Economic Principles of 'Affordability'. Urban Studies, 30(1), 127-145.

16. Hui, E. C. M. (1999). Public Housing Rents in Hong Kong: Policy And Structure. Urban Planning And Development, 125(1), 17.

17. Hui, E. C. M. (1999). Willingness to Pay for Better Housing in Hong Kong: Theory and Evidence (of Dwelling Space). Urban Studies, 36(2), 289 - 304.

18. Hulchanski, J. D. (1995). The concept of housing affordability: Six contemporary uses of the housing expenditure-to-income ratio. Housing Studies, 10(4), 471.

19. Kutty, N. K. (2005). A New Measure of Housing Affordability: Estimates and Analytical Results. HOUSING POLICY DEBATE 16(1), 113 - 141.

20. Lee, S.-P., \& Liu, D.-Y. (2002). The Determinants of Default in Residential Mortgage Payments: A Statistical Analysis. International Journal Of Management, 19(2), 377-389.

21. Lerman, D. L., \& Reeder, W. J. (1987). The Affordability of Adequate Housing. AREUEA, 15(4), 389 - 404.

22. Linneman, P. D., \& Megbolugbe, I. F. (1992). Housing Affordability: Myth or Reality? Urban Studies, 29(3/4), 369-392.

23. Lux, M. (2007). The Quasi-normative Approach to Housing Affordability: The Case of the Czech Republic. Urban Studies, 44(5/6), 1109-1124.

24. Mimura, Y. (2008). Housing Cost Burden, Poverty Status, and Economic Hardship among Lowincome Families. Family Economic Issue 29: 152-165.

25. Mohd Taib, D. (1993). Agihan Pembangunan: Teori dan Perlaksanaan (1 ed.). Kuala Lumpur: Dewan Bahasa Dan Pustaka.

26. Moss, V. (2003). Understanding the reasons to the causes of defaults in the social housing sector of South Africa. Housing Finance International, 18(1), 20 - 26.

27. Mostafa, A., et al. (2006). Factors Affecting the Housing Affordability of the Public Housing Tenants in Hong Kong. Paper presented at the International Conference On Sustainable Housing 2006, Universiti Sains Malaysia, Pulau Pinang.

28. Murray, M. S. (1997). Low-Income Renter Housing: Another View of the Tough Choice. Housing Research, 8(1), 27-51.

29. Nixon, J., \& Hunter, C. (1996). "It Was Humiliating Actually. I Wouldn't Go Again".: Rent Arrears and Possession Proceedings in the County Court. Netherland Journal of Housing and the Built Environment, 1T1 (4).

30. Nor'Aini, Y. (2007). Pemaju Swasta dan Perumahan Kos Rendah. Pulau Pinang: Universiti Sains Malaysia.

31. Norazmawati, M. S. A. R. (2006). Kemampuan Pemilikan Rumah Kos Rendah di Kuala Lumpur. Unpublished PhD Thesis, Universiti Sains Malaysia.

32. Sethu, R. R. (1986). Rent Control Legislation in Malaysia: Butterworth \& Co (Asia) Pte Ltd.

33. Stone, M. E. (2006). What is Housing Affordability? The Case for the Residual Income Approach. Housing Policy Debate, 7(1), 151-184.

34. Tabachnick, BG \& Fidell, LS 2007, Using multivariate statistics, 5th edn, Pearson/Allyn \& Bacon, Boston.

35. Thalmann, P. (1999). Identifying Households which Need Housing Assistance. Urban Studies, 36(11), 1933-1947.

36. Wood, E. H. (2006). The internal predictors of business performance in small firms. Small Business And Enterprise Development, 13(3), 441-453.

37. Yates, J., \& Wood, G. (2005). Affordable Rental Housing: Lost, Stolen and Strayed. The Economic Record, 81(Special Issue), S82-S95.

38. Zakiyah, J., et al. (2004). Rumah Kos Rendah: Masalah dan Penyelesaian (1 ed.). Sintok, Kedah: Universiti Utara Malaysia. 